\title{
NOTE XXXIII.
}

\section{DESCRIPTION OF A NEW SPECIES OF OLIVA.}

BY

\section{M. SCHEPMAN.}

\section{Oliva Semmelinki, n. sp.}

Shell oblong-cylindrical, spire exserted, with an obtuse apex; crean colour with a reddish-brown net-work, leaving triangular spaces, and with blotches of a more purplish tinge beneath the sutures and round the middle. The 3 spiral whorls unspotted, the two next with a reddish callosity occupying the lower part of the whorls. Basal part not divided with a few brown spots. Columella straight, with small whitish plaits, some of which are bifid. Interior of the aperture rose colour.

Total length 16 , breadth 6 , length of aperture 11 mill.

$H a b$. Strait of Larentoeka near Flores, collected by Dr. Semmelink.

This species has much the appearance of being a dwarfform of 0 . guttata var. mantichores, but it is much more cylindrical than .young specimens of that species. In form it approaches to australis but is sufficiently distinct in colour and in other particulars. 